Original Research

\title{
Urban Sprawl and its Impact on Soil and Plant Species in Peshawar, Pakistan
}

\author{
Kashif Ali, ${ }^{1,2}$, Muhammad Shuaib ${ }^{3 *}$, Tamoor Malik', Syed Sadaqat Shah', \\ Sajjad Ali ${ }^{5}$, Naseer Ali Shah ${ }^{6 * *}$, Fida Hussain ${ }^{7}$, Ikramullah Khan ${ }^{8}$, \\ Naveed Akhtar ${ }^{2}$, Zhijian $\mathrm{Li}^{1 * * *}$ \\ ${ }^{1}$ School of Life Sciences, Northeast Normal University, Changchun 130024, China. \\ ${ }^{2}$ Department of Botany, Islamia college Peshawar, Pakistan \\ ${ }^{3}$ School of Ecology and Environmental Science, Yunnan University, Kunming, Yunnan, P.R. China \\ ${ }^{4}$ Department of Statistics, Yunnan University, Kunming, China \\ ${ }^{5}$ Department of Botany, Bacha Khan University Charsadda, Pakistan \\ ${ }^{6}$ Department of Biosciences, COMSATS University Islamabad, Pakistan \\ ${ }^{7}$ Department of Botany, Qurtuba University of Science and Information Technology, Peshawar, Pakistan \\ ${ }^{8}$ Department of Botany, Abdul Wali Khan University Mardan, Pakistan
}

Received: 21 February 2018

Accepted: 29 May 2018

\begin{abstract}
The current paper aims to highlight: 1) Major problems due to urbanization, including land cutting, erosion, overgrazing, biodiversity loss, and climate change. 2) The impact of grazing on plant community structure and ecosystem functioning. 3) Management and conservation of natural ecosystems in Sheikh Muhammdi Peshawar.

For the current work, three different sites (Zones 1, 11, 111) were selected in the local area. The populations of the local area have increased very rapidly in the last 40 to 50 years. Anthropogenic activities associated with population and industrialization in the district, with vegetation clear for developing of towns and roads, has resulted in the substitution of vegetations with the dark color surface, the temperature of the environments much higher than before, leading to the phenomenon of the urban heat island effect. This urbanization and construction work at Amman plots Sheikh Muhammadi Peshawar is causing the extinction of vegetation and there would be no more wild vegetation in the near future in that particular area.
\end{abstract}

Keywords: urbanization, grazing, soil erosion, vegetation cover, Sheikh Muhammadi, Pakistan

*e-mail: zeyadz44@yahoo.com

**e-mail: drnaseeralishah@gmail.com

*** e-mail: khankhanafridi10@yahoo.com 


\section{Introduction}

Large areas of vegetation will have to be destroyed in order to develop more towns. Naturally, vegetated surfaces will be replaced by buildings and paved streets. Peshawar has increased from 0.5 million to 4.2 million. But most importantly, the additions of vegetation are usually lagging behind urban development. Humaninduced disruption also has a reflective impact on vegetation and soil. The major anthropogenic activity is urbanization, which completely reduces the cover of vegetation [1]. Environmental and vegetation protection is a huge issue globally [2]. Related to other variables like industrial construction, it is one of the main sources of pollution - including air and water pollution [3]. Construction of buildings has a direct and indirect effect on humans and vegetation [4]. One of the big problems of the environment is the rapidly increasing human population. The formation of agricultural land is the most important way because in the future arable land is not increasing, and in fact is probably decreasing, due to erosion and land deterioration. The huge population creates extra pressure on the environment. The success of plants is due to the interaction between soil and other major abiotic factors like soil, water, and light, which change in the water contents. The major consequence of this change is the amelioration of soil [5], which results in the alteration of the hydrologic characteristics of the site [6]. Below the vegetation cover, the addition of organic matter and the moderation of soil microclimate provide a significant zone for microbial activity and the creation of water-stable soil aggregates [7]. The branch of science in which we study a plant relationship with its environment - including soil texture, structure, and their composition - also is developing [8].

The objectives of our paper are to highlight the major problems due to urbanization, including land cutting, erosion, overgrazing, biodiversity loss, and climate changes, the impact of grazing on plant community structure and ecosystem functioning, and managing and conserving natural ecosystems in Sheikh Muhammdi Peshawar. The outcome of this survey can help the government prepare proper sustainability plans and also increase knowledge through training and awareness programs. Further research needs to investigate the on-site sustainable performance measurements using identified environmental impacts in advance. A large area of vegetation is being replaced with buildings, roads, and another hard surface, and this survey determines the impact of construction on vegetation and on the soil of the area.

\section{Materials and Methods}

Four study sites were selected in the Sheikh Mohammadi area of the Peshawar District for phytosociological investigations. The sites were selected on the basis of physiognomy, to get an accurate image of the vegetation of the whole area. Expeditions were conducted to five sites in spring 2016 following standard locality procedures [9]. Sampling was carried out systematically using the quadrat method and a quadrat size of $4 \times 4 \mathrm{~m}$ throughout the study. Sampling was started at the initial margins of each zone and quadrats were laid onward after every $100 \mathrm{~m}$. Species data, including cover, frequency, and density was recorded from the sites following [10, 11]. The collected specimens were pressed, dried, and mounted on standard herbarium sheets. The specimens were then identified with the help of Flora of Pakistan [12]. The Voucher specimens were deposited into the herbarium at the Department of Botany, Islamia College University Peshawar, and Khyber Pakhtunkhwa, Pakistan. Composite soil samples were taken from all Quadrats of each study site and physicochemical analyses were conducted at the Agricultural Research Institute in Tarnab, Peshawar. These soil parameters analyzed organic matter, $\mathrm{pH}$, saturation, texture, phosphorus (ppm), and potassium (ppm). The above-mentioned parameters were calculated with the following formulae:

Density

$$
\text { Density } / \mathrm{m}^{2}=\frac{\text { Total number of plants species }}{\text { present in all quadrates }}
$$

$$
\text { Relative density (\%) }
$$

Relative density will be computed by the following formulae:

$$
\text { Relative density }=\frac{\text { Density of individual }}{\begin{array}{c}
\text { Species } \\
\text { Total density of all } \\
\text { species }
\end{array}} \times 100
$$$$
\text { Frequency (\%) }
$$$$
\text { Frequency }=\frac{\text { Number of quadrates in which }}{\text { the species present }} \times 100
$$

Relative Frequency (\%)

Relative frequency $=\frac{\begin{array}{l}\text { Frequency value of } \\ \text { a single species } \\ \text { Total frequency }\end{array}}{X 100}$

Importance Value

Importance value $=$ Relative density + Relative frequency+ Relative cover 


\section{Canopy Cover}

Cover is the vertical projection of foliage shoots/ crown of a species to the ground surface expressed as a fraction or percentage of surface area.

$$
\text { Cover }=\frac{\% \text { Cover of a species }}{\text { Total cover of all species }}
$$

Relative Cover $=\frac{\text { Cover of a species x100 }}{\text { Cover of all species }}$

\section{Soil Analysis}

Soil samples were collected from 3 sites $(1 \mathrm{~kg}$ dry soil) of Sheikh Muhammadi District in Peshawar and sent to the Agriculture Research Institute (ARI) in Tarnab, Peshawar, for physico-chemical analysis. Soil samples were taken from all quadrats of each study site and physico-chemical analyses were conducted at ARI. The soil parameters investigated included soil organic matter, $\mathrm{pH}$, saturation, texture, phosphorus (ppm), and potassium ( $\mathrm{ppm}$ ), and calculated using the following formulae:

\section{Statistical Methods}

For data analysis we used Amos Graphic and SPSS 21 to analyze the data.

\section{Results and Discussion}

The current results are a focus to finding the urbanization issue and vegetation cover in the Amman plots of Sheikh Muhammadi in Peshawar, Pakistan. The area is divided into 3 zones: Khyber Fields (Zone 1), grid stations (Zone 11), and Amman Plots (Zone 111). Urbanization exerts a substantial effect on biodiversity, resulting in the loss of native species and the introduction of non-native species. The present research emphasizes the impact of urbanization, which refers to the shifting of population from the nearby area to Sheikhmuhammadi. The accumulated amount of adverse effect on the vegetation occurs and also produce waste, noise, and dust, and is hazardous for the same impact on construction $[13,14]$. Soil erosion is a major naturally occurring process on all land and many agents of soil erosion are responsible for water and wind. In grid satiation the soil erosion was done by water, and this erosion causes a significant amount of soil loss each year in grid satiation.

\section{Soil Analysis}

Soil is one of the important abiotic components of the environment because it is the ultimate source of minerals nutrients. Best soil management ensures that

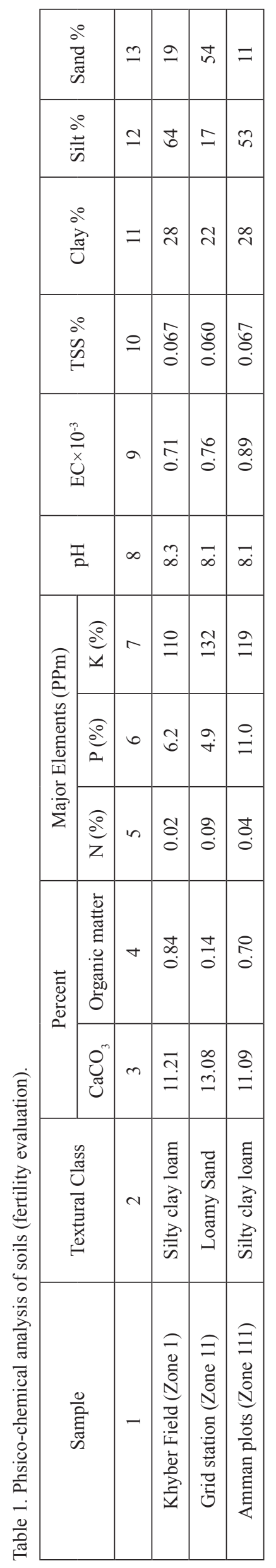


the mineral element does not become deficient and toxic for plants. The physicochemical analysis of soil showed two different kinds of texture of soil, including silty clay loam and loamy sand (Table 1).

\section{Physicochemical Analysis of Khyber Field Soil (Zone 1)}

The texture of this zone is silty clay loam, the amount of nitrogen is $0.02(\%)$, potassium is $6.2 \%$, Potassium $110 \%$, and $\mathrm{pH}$ of the soil is 8.3 . On the basis of size, particle silt and clay particles are respectively prominent by $64 \%$ and $28 \%$. Khyber field area soil shows the best texture for the agriculture field [15].

\section{Physicochemical Analysis of Grid Station Soil (Zone 2)}

The texture of this zone is loamy sand, the amount of nitrogen is $0.04(\%)$, potassium is $11.0 \%$, potassium $119 \%$, and $\mathrm{pH}$ of the soil is 8.1 . On the basis of size, particle sand and clay particles are respectively prominent at $54 \%$ and $22 \%$. In recent year agriculture was also done by the local people, but due to the formation of grid station, the soil becomes eroded due to lack of vegetation and agricultural practice [16].

\section{Physicochemical Analysis of Amman Plot Soil (Zone 3)}

The texture of this zone is Silty clay loam, the amount of nitrogen is $0.09 \%$, potassium is $4.9 \%$, Potassium $132 \%$, and $\mathrm{pH}$ is 8.1 . On the basis of particle sizes, silt and clay particles are the most prominent at, respectively, $53 \%$ and $28 \%$. The soil texture of this zone is best for the agriculture but due to starting construction work it is no more in agricultural use. The management of soil is also important for the productivity of crops, environmental sustainability, and human health. Because of the projected increase in world population and the consequent necessity for the increase of food production, the management of soils will become increasingly important in coming years. This is the first attempt to analyze the impact of urbanization and grazing of Sheikh Muhammadi in District Peshawar.

\section{ZONE 1. Khyber Field}

\section{Phytosociological Study}

On the basis of the physicochemical analysis of soils, Khyber Field is one of the fertile sites of the research area. Physicochemical analysis of soils showed that it had silty clay loamy soil, which is the best for agriculture and plant growth. Major elements N, P, and $\mathrm{K}$ are present in sufficient amounts $(0.02 \%, 6.2 \%$, $110 \%$ - Table 1), and due to fertile soil this site showed a huge amount of the flora which is the most prominent among the other sites of the research. The present survey reported 28 plant species that were reported during phytosociological studies. The Parthenium hysterophorus community dominated, showing the important value of 13.665 , followed by Setaria viridis at 11.796, Eclipta alba at the least important value of 1.730 , followed by Calotropis procera at 1.908 (Fig. 1).
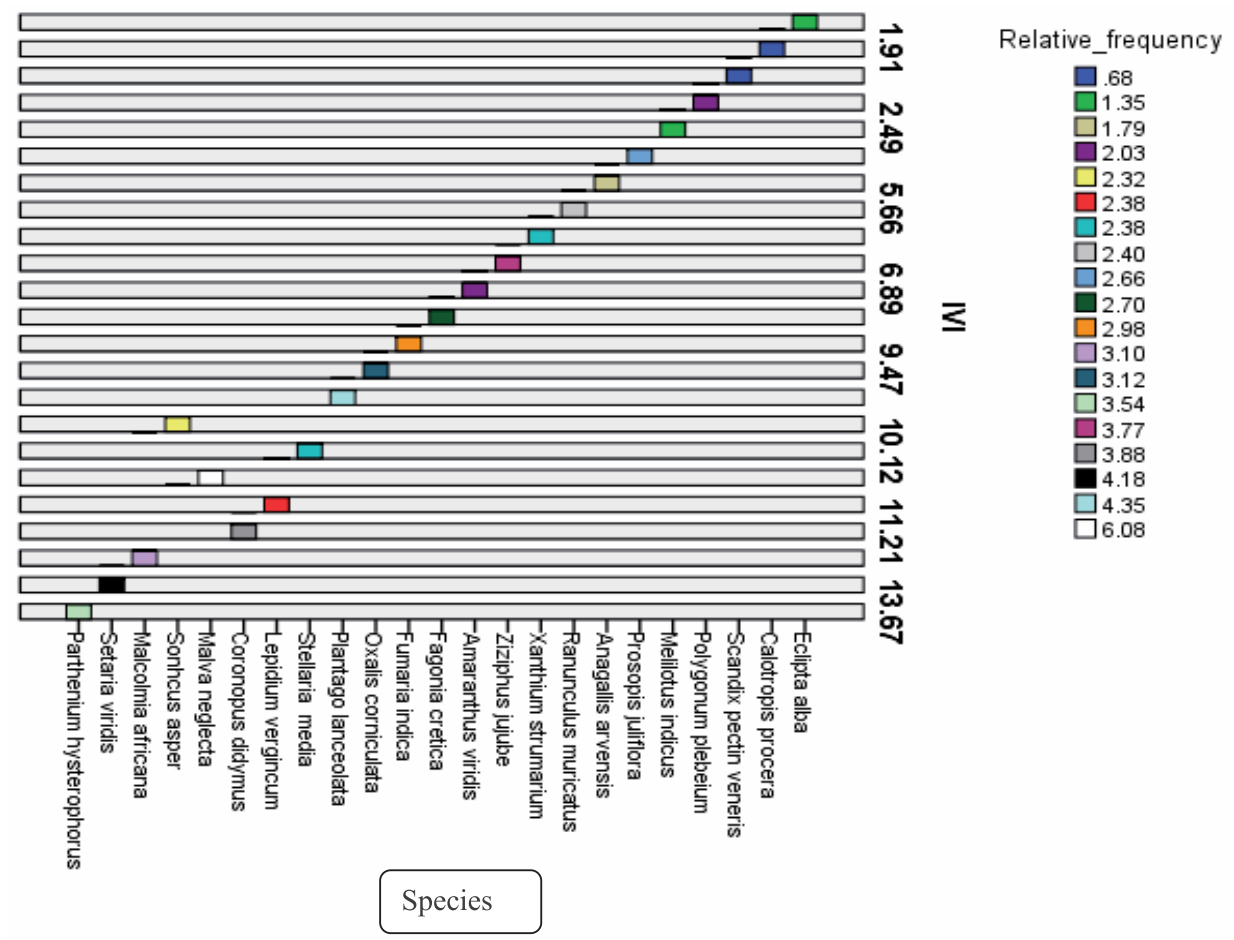

Fig. 1. Importance value index and relative frequency of Khyber Field (Zone 1). 


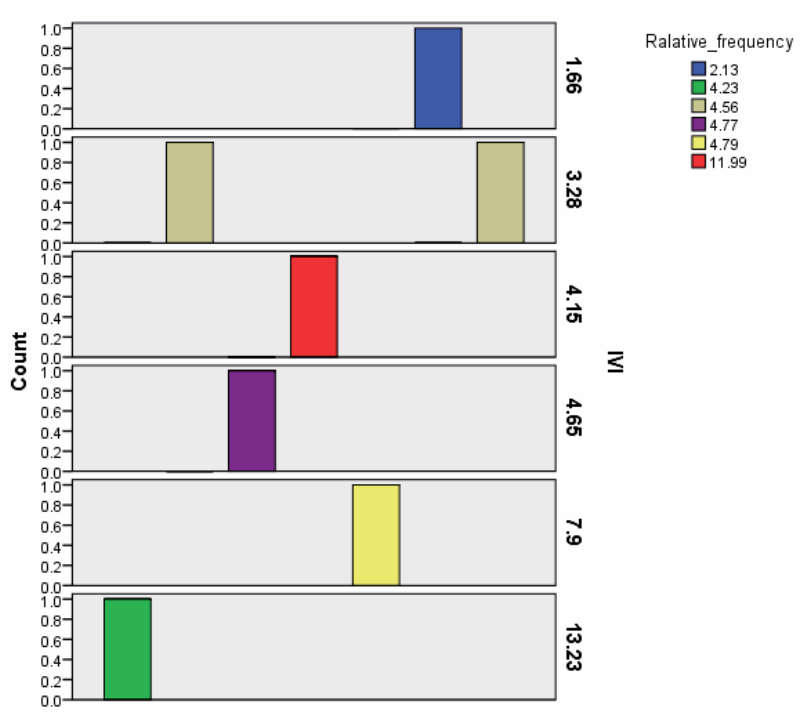

Fig. 2. Importance value index and relative frequencyof grid station (Zone 2).

\section{Khyber Field and its Impact}

Overgrazing and cutting of plant species also showed a great impact on the native flora and soil in the Khyber field area [17]. A total of 23 plant species were reported in Khyber Field. Excessive grazing animals like cow, goat, and buffalo, and the misuse of these herbaceous species, reduced the native flora at a great rate (Fig. 4). In this study, the low values in total vegetation cover and aboveground biomass in under-grazing grassland can be attributed to grazing sheep and goats that affected vegetation growth directly through consumption and trampling, or due to the nature of plant species that grow under grazing (prostrate species, dwarf species, species with medium-specific leaf area, etc.) $[18,19]$. Hence, the present results are consistent with observations from other studies that have attempted to relate changes in vegetation to rainfall and grazing intensity [20, 21].

\section{ZONE 11. Grid Station}

This report covers the technical audit of Sheikh Muhammadi (Peshawar) $500 \mathrm{kV}$ Grid Station (GS) located near Indus highway about $13 \mathrm{~km}$ from Peshawar, KPK. The GS was commissioned on December 8, 1995. It has 900 MVA transformation capacity connected to the grid out of the installed capacity of 1350 MVA feeding a major portion of KPK. There are three (03) 450 MVA-500/220 kV autotransformer banks, three (03) 160 MVA - 220/132 kV, one (01) 250 MVA-220/132 kV autotransformers, and two (02) 10/13 MVA-132/11 kV power transformers at this GS that are owned and maintained by NTDC. One (01) $500 \mathrm{kV}$, four (04) $220 \mathrm{kV}$, and eight (08) $132 \mathrm{kV}$ transmission circuits link this station to others (Figs 4-5). The GS is connected to Tarbela Hydropower Station through $500 \mathrm{kV}$ single circuit four bundled transmission lines and to Ghazi Barotha Hydropower Station, Shahibagh $220 \mathrm{kV}$, and Daud Khel $220 \mathrm{kV}$ GS. $500 \mathrm{kV}$ and $220 \mathrm{kV}$ switchyards use a 1.5 breaker scheme, whereas a $132 \mathrm{kV}$ switchyard uses a double-bus single-breaker scheme. A single line diagram is attached [22]. It covers

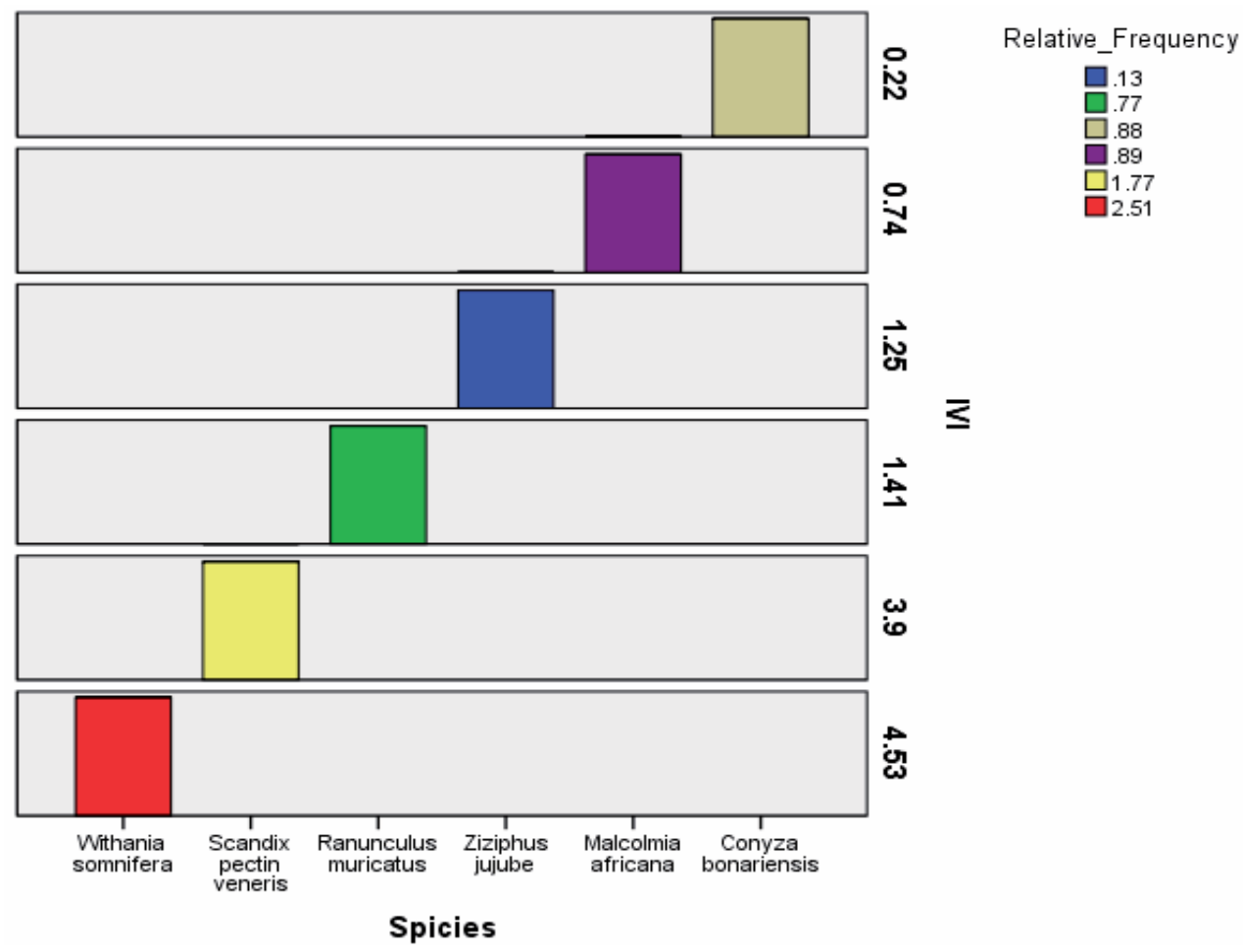

Fig. 3. Importance value index and relative frequencyof Amman Plots Sheikh Muhammadi (Zone 3). 
a huge area of the Sheikh Mohammadi, which covers a large agriculture area.

\section{Phytosociological Study}

Grid stations are the $2^{\text {nd }}$ area of the research site according to the phytosociological study Amaranthus viridis dominating the community showing the highest IVI 22.67, Lepidium vergincum18.13, and Setaria viridis 18.132 (Fig. 2). The soil fertility analysis showed loamy sandy texture for major elements like N, P, K 0.09, 4.9, and 132 shown in Table 1.

\section{Main Issue of the Grid Station}

The soil texture of the grid station showed loamy sand texture, which is best for the agriculture also, but the area is completely filled by a huge electricity pole, for which serious damage to the soil texture as well and also the gate causes soil erosion [23]. Due to excessive rain and lack of vegetation the soil is gradually eroded and will be completely removed in the future [24].

\section{Soil Erosion}

In many areas of the grid station the loss of topsoil through removal of the entire vegetation also causes mineral imbalance and erosion. This is one of the main and large threats to agricultural productivity. The topsoil sustains most living organisms, being the ultimate source of their mineral nutrients, the mentioned effects like soil erosion affects the community of plants if the texture and structure of the soil is changed with the mentioned issue, and the mentioned issue was also reported for various parts of the world [25, 26]. The land of grid station is known as completely eroded and loses its capability and top soil layer (Fig. 4). In this zone, soil erosion is one the causes of soil degradation. Soil erosion is one form of soil degradation along with soil compaction, low organic matter, and loss of soil structure. These other forms of soil degradation, serious in themselves, usually contribute to accelerated soil

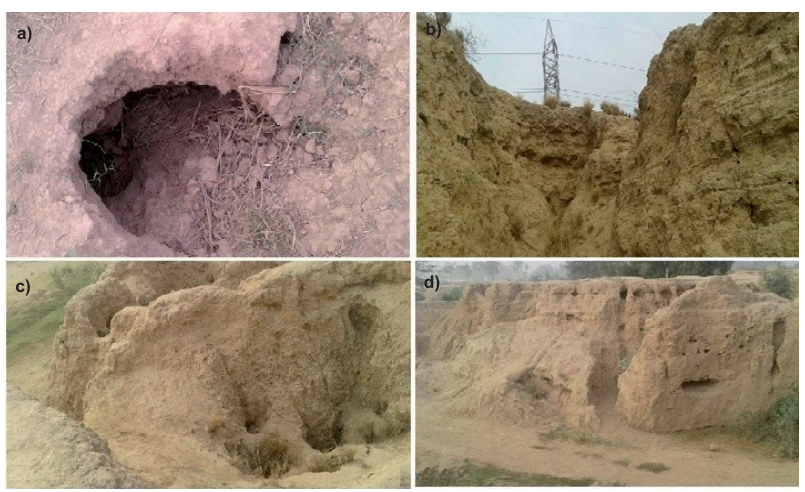

Fig. 4. a), b), c), and d) represent soil erosion in Zone 11 grid station of Sheikh Mhammadi, Peshawar. erosion. Soil erosion potential is increased if the soil has no or very little vegetative cover of plants and/or crop residues. Plant and residue cover protects the soil from raindrop impact and splash, tends to slow down the movement of surface runoff, and allows excess surface water to infiltrate.

\section{Zone 111. Amman Plots Sheikh Muhammadi}

\section{Phytosociological Studies}

The vegetation of the Amman plots Sheikh Muhammadi is very low at just 6 species because of construction and cutting the dominating communities of Withania somnifera IVI 4.53, Scandix pectin veneris 3.897, and Ranunculus muricatus 1.410 (Fig. 3). Nearby tree species are removed because of the mentioned activity, and the growth of cities may cause biodiversity to decline in a large area of natural habitat on which many plant species depend.

\section{The Main Issue in Zone 111}

\section{Impact of Construction}

The constructions are responsible for using a large volume of natural resources and generate a great amount of pollution in present days as well in the future. The same issue was also reported by [27, 28]. Although there are many causes of habitat loss, urbanization has been shown to be one of the most damaging in terms of a number of plant species loss or threats to them (Figs 3,5). Construction work will cause the extinction of the vegetation [29-32]. The land that is conducive and fertile for agriculture will be no more in the upcoming year. The other major problems like urban heat and increases in temperature will be more prominent in the near future due to heavy traffic and industries, and the same result was also reported by [33, 34]. Huge land of vegetation will have to be finished because of new cities and towns. This agricultural area will be replaced by roads and streets [35].

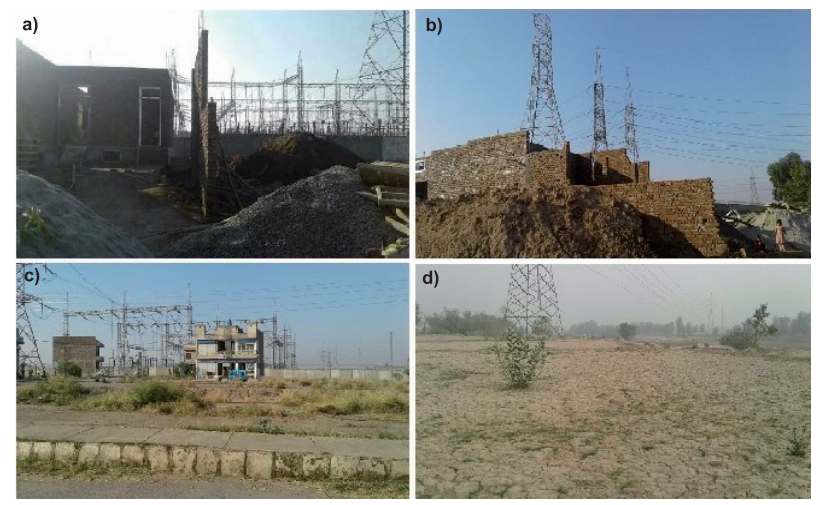

Fig. 5. a), b), and c), represent the construction in Zone 111 Amman Plots and d) represents the wastelands of Sheikh Muhammadi in Peshawar, Pakistan. 


\section{Novelty and Conclusion}

In Peshawar District the populations are increasing with high ratio and people are shifting from the main city to the allied areas of the district. A lot of issues have arisen with the increase of population. The local area Sheikh Muhammadi has seen so many issues in recent years, including urbanization, grazing, loss of vegetation, and soil erosion. These problems are raised because of the majority of people involved in the destructive cutting of vegetation and extreme grazing. A few species are affected in the local area and have become endangered (peganum harmella is extinct, for example). The new town is developed through which the agriculture land is nearly covered by homes and road, and vegetation is fully disturbed. Overthe last 10 years the land has become continually eroded due to vegetation removal, and it is totally disturbed by rain, as shown in Fig. 4.

\section{Conflict of Interest}

All the authors declare no conflict of interest.

\section{Acknowledgements}

The authors gratefully acknowledge the support received from ICP Peshawar. This research work received no specific grant from any donor agency in the public, commercial, or not-for-profit sectors, and these organizations have had no involvement in the analysis and interpretation of data, in the writing of the draft, and in the decision to submit the article for publication.

\section{References}

1. DAWSON R.J., HALL J.W., BARR S.L., BATTY M., BRISTOW A.L., CARNEY S., DAGOUMAS A., EVANS S., FORD A., HARWATT H., KÖHLER J., TIGHT M.R., WALSH C.L., ZANNI A.M. A blueprint for the integrated assessment of climate change in cities. Tyndall Working Paper 129, 26, 2009.

2. TSE Y., RAYMOND V. The implementation of EMS in construction firms: a case study in Hong Kong". Journal of Environmental Assessment Policy and Management 3, 94, 2001.

3. SHEN L.Y., LU W.S., YAO H., WU D.H. A computerbased scoring method for measuring the environmental performance of construction activities. Automation in Construction 14, 297, 2005.

4. LEVIN H. Systematic Evaluation and Assessment of Building Environmental Performance (SEABEP). paper for presentation to 'Buildings and Environment' Paris, 9, 1997.

5. FISHER R.F. Amelioration of soils by trees. p. 290-300. In: S.P. Gessel, D.S. Lacate, G.F. Weetman, and R.F. Powers (eds.), Sustained productivity of forest soils, Proceedings of the 7th North American Forest Soils Conference. Univ. British Columbia, Vancouver.1990.

6. THUROW T.L. Hydrology and erosion. pp. 141-159. In: R.K. Heitschmidt and J.W. Stuth (eds.). Grazing Management: An Ecological Perspective. Timber Press, Portland, Oregon. 1991.

7. KITTREDGE J. Forest influences. McGraw-Hill Book Co. Inc., New York, N.Y. 1948.

8. EWALD J. A critique for phytosociology.J. Veg. Sci. $\mathbf{1 4}$ (2), 291, 2003.

9. COX W.G. Laboratory Manual of General Ecology. WMC Brown Co. Dubuque, IA. 1967.

10. CURTIS J.T. The vegetation of Wisconsin. Madison: University of Wisconsin Press, 657, 1959.

11. OOSTING H.J. The study of plant communities. San Francisco: Freeman Publishing, Inc. 440, 1956.

12. NASIR E., ALIS.I. "Flora of West Pakistan", Department of Botany, University of Karachi, Karachi. 1971-95.

13. CHEN Z., LI H., WONG C.T.C. Environmental Management of Urban Construction Projects in China". Journal of Construction Engineering andManagement 126, 320, 2000.

14. CHEN Z., LI H., HONG J. An integrative methodology for environmental management in construction". Automation in Construction 13, 621, 2004.

15. KAYOMBO B., LAL R. Tillage systems and soil compaction in Africa. Soil Till. Res. 27, 35, 1993.

16. BARTHEL S., ISENDAHL C. Urban gardens, agriculture, and water management: Sources of resilience for long-term food security in cities. Ecol. Econ. 86, 224, 2013.

17. WHISENANT, S.G. Changing Fire Frequencies on Idaho's Snake River Plains: Ecological and Management Implications. Pages 4, 1990.

18. ALI K., SHUAIB M., HUSSAIN Z., SAJJAD W., ALI F., FAZIL M., Ethnobotanical assessment of the medicinal flora of Khyber agency, Pakistan. Pak. J. Weed Sci. Res. 22 (4), 607, 2016.

19. PECO B., DE PABLOS I., TRABA J., LEVASSOR C. The effect of grazing abandonment on species composition and functional traits: the case of dehesa. Basic Appl. Ecol. 6 (2), 175, 2005.

20. LAUENROTH W.K., SALA O.E. Longterm forage production of North American shortgrass steppe. Ecological Applications. 2, 397, 1992.

21. BIONDINI M.E., PATTON B.D., NYREN P.E. Grazing intensity and ecosystem processesin a northern mixed-grass prairie, USA. Ecological Applications. 8, 469, 1998.

22. USAID. energy policy program technical audit report Sheikh Mohammadi. 2015.

23. THOMAS D.A., SQUIRESV.R. Available Soil Moisture as a Basis for Land Capability Assessment in Semi-Arid Regions. Plant Ecology 91 (1-2), 183, 1991.

24. WHEELER M.A., TRLICAM.J., FRASIER G.W., REEDERJ.D. Seasonal Grazing Affects Soil Physical Properties of a Montane Riparian Community. Journal of Range Management 55, 49, 2002.

25. SINGER M.J., MUNNSD N. Soils: An Introduction $\left(2^{\text {nd }}\right.$ edition). MacMillan publishing company, New York. 473,1987.

26. WERNER H. Measuring Soil Moisture for Irrigation Water Management. South Dakota State University Cooperative Extension Service, 2002.

27. LI X., ZHU Y., ZHANG Z. An LCA-based environmental impact assessment model for construction processes". Building and Environment 45, 766, 2010. 
28. MOREL J.C., MESBAH A., OGGERO M., WALKER P. Building houses with local materials: means to drastically reduce the environmental impact of construction". Building and Environment 36, 1119, 2001.

29. FABRIZI R., BONAFONI S., BIONDI R. Satellite and Ground-Based Sensors for the Urban Heat Island Analysis in the City of Rome, Remote Sensing, 2, 1400, 2010.

30. HAMDI R. Estimating urban heat island effects on the temperature series of uccle (Brussels, Belgium) using remote sensing data and a land surface scheme, Remote Sensing, 2, 2773, 2010.

31. LIU L., ZHANG Y.Z., Urban heat island analysis using the landsat TM data and ASTER data: A case study in Hong Kong, Remote Sensing, 3, 1535, 2011.
32. XIONG Y.Z., HUANG S.P., CHEN F., YE H., WANG H., ZHU C.B. The impacts of rapid urbanization on the thermal environment: a remote sensing study of Guangzhou, South China, Remote Sensing.4, 2033, 2012.

33. GLUCH R., QUATTROCHI D.A., LUVALL J.C. A multiscale approach to urban thermal analysis, Remote Sensing of Environment.104, 123, 2006.

34. VOOGT J.A., OKE T.R. Thermal remote sensing of urban areas, Remote Sensing of Environment. 86, 370, 2003.

35. SHUAIB M., ALI K., AHMED S., HUSSAIN F., ILYAS M., HASSAN N., HUSSAIN F., Impact of rapid urbanization on the floral diversity and agriculture land of district Dir, Pakistan, Acta Ecol. Sin. 38, 394, 2018. 